\title{
Changes in the Road Traffic Laws and Their Relationship with Head Trauma in a Medium- Sized City of Brazil
}

Mudanças da Lei de Trânsito e Sua Correlação com Traumas Crânio-Encefálicos em Cidade de Médio Porte no Brasil

Moacir Alves Borges ${ }^{1}$, Fernando Manuel Rana Filipe ${ }^{2}$

\begin{abstract}
Traumatic brain injury (TBI) is the leading cause of disability, morbidity and mortality in young people. As these individuals are vulnerable to the consumption of alcoholic beverages, this is a major public health issue with a high impact on socioeconomic costs. This study analyzed 138 patients treated at Hospital de Base for TBIs due to traffic accidents inside the urban area of Sao Jose do Rio Preto in the period from 2005 to 2008 . Of these patients, 115 were male $(83.3 \%)$ with a mean age of 38.9 years and 23 were female with a mean age of 42.4 years. There was a statistically non-significant decrease in the frequency of TBIs in the first half of 2008, that is, when stricter drink-driving laws were introduced. We conclude that urban TBIs predominantly affect young men and that there was no statistical correlation between the introduction of stricter drink-driving laws and a reduction in TBIs.
\end{abstract}

Keywords. Traumatic Brain Injury, Traffic Laws, Traffic Accidents.

Citation. Borges MA, Filipe FMR. Changes in the Road Traffic Laws and Their Relationship with Head Trauma in a Medium-Sized City of Brazil.

\section{RESUMO}

O traumatismo crânio encefálico (TCE) é a maior causa de incapacidade, morbidade e mortalidade na população jovem que é vulnerável ao consumo de bebidas alcoólicas, tornando-se uma questão de saúde pública com grande importância e influência no custo sócio econômico da população. Esse estudo analisou 138 pacientes atendidos no Hospital de Base vítimas de TCE por acidente de trânsito no período de 2005 a 2008 dentro do limite urbano da cidade de São José do Rio Preto. Destes pacientes, 115 eram do sexo masculino (83,3\%), com idade média de 38,9 anos e 23 eram do sexo feminino com idade média de 42,4 anos. Foi observado queda da freqüência do TCE no primeiro semestre de 2008, época do início da lei seca, porém sem significado estatístico. Concluímos que o TCE urbano ocorre predominantemente em homens jovens. Não houve correlação estatística entre o início da lei seca e redução na ocorrência do TCE.

Unitermos. Traumatismo Craniencefálico, Código de Trânsito, Acidente de Trânsito.

Citaçáo. Borges MA, Filipe FMR. Mudanças da Lei de Trânsito e Sua Correlação com Traumas Crânio-Encefálicos em Cidade de Médio Porte no Brasil.
Study performed at Hospital de Base de São José do Rio Preto, São José do Rio Preto-SP, Brasil.

1.MD, PhD, Professor of the Neurological Sciences Department of the Medicine School in São José do Rio Preto, São José do Rio Preto, SP, Brazil

2.M.Sc. in Health Sciences; Neurosurgeon of the Neurological Sciences Department of the Medicine School in São José do Rio Preto, São José do Rio Preto, SP, Brazil.
Endereço para correspondência: Prof. Dr. Moacir A Borges Av José Munia 4850

CEP 15090 500, São José do Rio Preto-SP, Brasil. E-mail: moacirab@hotmail.com

Original

Recebido em: 23/09/10

Aceito em: 26/10/11

Conflito de interesses: não 


\section{INTRODUCTION}

Traumatic brain injuries (TBIs) are the main cause of disability, morbidity and mortality in the young population ${ }^{1}$. TBIs cause alterations in brain functioning often manifested as mental confusion, impaired consciousness, epilepsy, coma, motor deficiency or focal sensitivity ${ }^{2-5}$.

In recent years there has been a significant growth in the number of post-trauma brain lesions as a result of increased urbanization and the use of motor vehicles; increases of $600 \%$ have been reported in Mexico, $450 \%$ in Thailand, 250\% in Venezuela and 200\% in Chile .

Alcohol consumption, driving and multiple injuries are associated with TBIs and thus constitute important risk factors. Between one quarter and a half of accident victims with TBIs are under the influence of alcohol, a situation which is more common in young adults. This risk factor increases mortality and also prejudices the initial evaluation of the patient with surgical-clinical measures being taken for severe TBI when in fact the head injury is mild and the reduced level of consciousness is related to alcohol consumption ${ }^{7}$.

This study analyses the effect on the frequency of TBIs of a Brazilian federal law which came into force in June 2008 and that reduced the legal blood alcoholic limit for drivers as well as making sentencing of drunk drivers much more severe (Law no 11705/08).

\section{METHOD}

Patients with TBI, victims of urban road traffic accidents, attended and hospitalized in Hospital de Base in the city of São José do Rio Preto in the period from January 2005 to December 2008 were evaluated in this study. São José do Rio Preto is a medium-sized city with a population of around 400,000 inhabitants ${ }^{8}$.
The patients' gender and age were recorded as were the etiology and month and year of the injury. The design of this study was approved by the Institutional Research Ethics Board (422/2008).

\section{Statistical analysis}

The Fisher exact, goodness of fit (chi-square), Kruskal-Wallis and two-sample tests were employed in the statistical analysis with the level of significance being set for a $\mathrm{p}$-value $\leq 0.05$.

\section{RESULTS}

A total of 138 victims of road traffic accidents were included in this study. One hundred and fifteen of the patients were men with a mean age of 38.9 years old (Range: 4 to 85 years; standard deviation $=20.5$ ); the majority of the victims (52.2\%) were between 19 and 40 years old. Only 23 (16.7\%) women suffered TBI and their mean age was higher than that of the men (Table 1).

Figure 1 shows patients with TBIs grouped as victims of car crashes, pedestrian-motor vehicle collisions, and motorbike and bicycle accidents as a percentage of the total TBIs attended in the emergency department of the hospital. No statistically significant variations were identified during the study period for the three different groups of road traffic accidents.

The gender of TBI patients involved in traffic accidents as a percentage of all TBIs attended in the Emergency Department was assessed (Figure 2).

On comparing the percentages of TBIs for the different age groups, there were no significant variations between 6-month intervals over the four years.

The total numbers of TBIs in the different age ranges were as follows: under 18-year-old age group - 10

Table 1

Gender and mean ages of the 138 patients who suffered TBI due to road traffic accidents attended in the Emergency Department of Hospital from January 2005 to December 2008

\begin{tabular}{ccccc}
\hline Gender & $\mathbf{N}^{\mathbf{*}}$ & Mean $^{* *}$ & Range & Standard deviation \\
\hline Female & $23(16.7 \%)$ & 42.4 & $17-83$ & 20.3 \\
Male & $115(83.3 \%)$ & 38.1 & $4-85$ & 17.3 \\
Total & 138 & 38.9 & $4-85$ & 17.8 \\
\hline
\end{tabular}

${ }^{*} \mathrm{p}$-value $=.0005 ;{ }^{* *} \mathrm{p}$-value $=.03$ 
Distribution of percentage of the traumatic brain injuries in eight half-years, considering car crashes and pedestrian-motor vehicle collisions

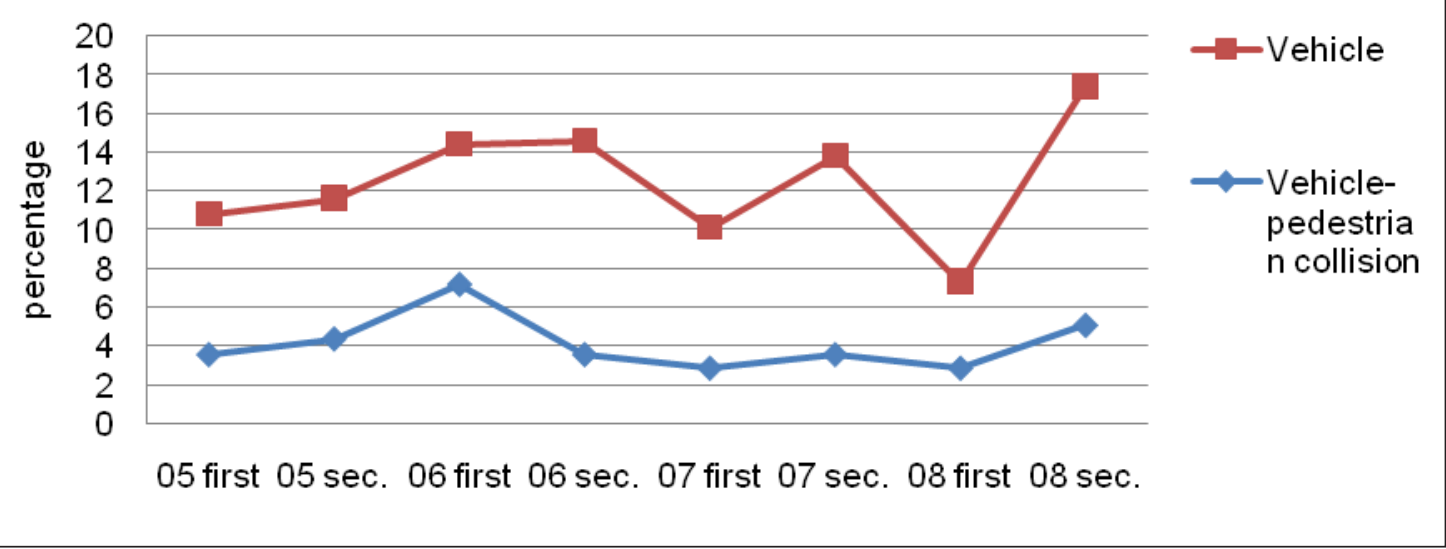

Figure 1. Road traffic accident victims with head injuries as a percentage of all traumatic brain injuries attended in the Emergency Department from January 2005 to December 2008.

Vehicle-pedestrian collisions $\mathrm{p}=0.6$ and vehicle crashes $\mathrm{p}=0.3$

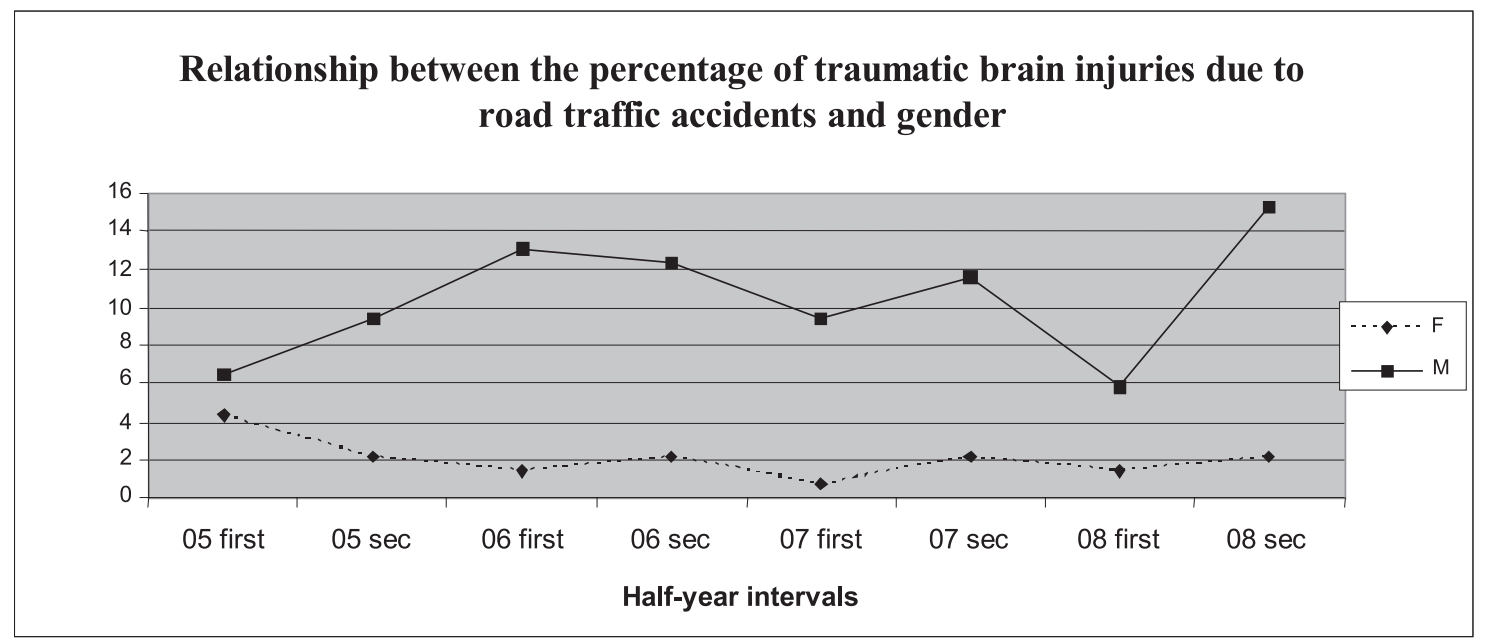

Figure 2. The relationship between the percentage of traumatic brain injuries due to road traffic accidents and gender $(\mathrm{p}=0.000)$. The variation in the number of victims comparing 6-monthly periods was not significantly different for both women $(\mathrm{p}=0.7)$ or men $(\mathrm{p}=0.2)$.

(7.2\%); 19 to 40-year-old group - $72(52.2 \%) ; 41$ to 65-year-old group - $44(31.9 \%)$ and over 65-year-old group - 12 (8.7\%). Thus, when the total number of TBIs is analyzed, there is no significant difference between age groups $(\mathrm{p}$-value $=0.0001)$. However, there is a significant difference when the elderly group (over 65 years old) is compared with adults (19 to 65 years old p-value = 0.001 ) and also when the adult group (19 to 65 years old) is compared with the youngest group (up to 18 years old $\mathrm{p}$-value $=0.000)$.

\section{DISCUSSION}

The aim of this study was to better understand TBIs caused by road traffic accidents in the urban area of São José do Rio Preto and thus provide information for future preventive measures. Similar to other publications on this subject ${ }^{9-11}$ this work showed that TBI are more common in 20 to 40 -year-old men ${ }^{7}$. This may be explained by the fact that men, especially young men, expose themselves to greater risk, such as drinking excessive alcohol and speeding, as this is subject to the so-called testosterone effect ${ }^{12-14}$. 
One interesting and at the same time worrying datum became evident when the numbers of victims during six-month periods were compared over the four years of the study. There was a reduction in the percentage of road traffic accident victims with TBI compared to all TBI victims attended in the Emergency Department in the first six months of 2008. This reduction in TBI was seen even when only accidents related to traffic accidents (car crashes, pedestrian-motor vehicle collisions, motorbike accidents and bicycle accidents) were considered. This period coincides with the introduction of a law that reduced the legal blood alcohol limit for drivers and increased the punishment of drivers who contravene the law. Even so this reduction was statistically insignificant and six months after the introduction of the law there was a return to pre-law figures. Remembering that the law remains in force, this drop occurred for another reason, for example, because of police actions against drunk driving.

Queiroz et al. concluded that the solution to the problem of traffic accidents involving drunk driving requires not only strict enforcement of laws but the implementation of public policies that take into account the cultural dimension and emphasize education programs against drunk driving ${ }^{15}$.

TBIs due to road traffic accidents constitute a socioeconomic problem, mainly because these injuries are very prevalent in young economically active adults ${ }^{16}$.

This study shows that a change in the drink-driving law is not sufficient in itself to permanently reduce the occurrence of TBIs caused by road traffic accidents, as the observed drop in numbers was due to other factors such as, for instance, an increase in policing and the marketing during the implantation of the new law.

\section{ACKNOWLEDGMENT}

The authors wish to thank the statistician José Antonio Cordeiro PhD, of the Statistics Department of the Medicine School in São José do Rio Preto for help with statistical analysis.

\section{REFERENCES}

1.Bruns J, Hauser WA. The epidemiology of traumatic brain injury: A review. Epilepsia 2003;44(suppl.10):2-10.

http://dx.doi.org/10.1046/j.1528-1157.44.s10.3.x

2.Tasaki O, Shiozaki T, Hamasaki T, Kajino K, Nakae H, Tanaka H, et al. Prognostic Indicators and Outcome Prediction Model for Severe Traumatic Brain Injury. J Trauma 2009;66:304-8.

http://dx.doi.org/10.1097/TA.0b013e31815d9d3f

3.Vespa PM, Nuwer MR, Nenov V, Ronne-Engstrom E, Hovda DA, Bergsneider $\mathrm{M}$, et al. Increased incidence and impact of nonconvulsive and convulsive seizures after traumatic brain injury as detected by continuous electroencephalographic monitoring. J Neurosurg 1999;91:750-60.

http://dx.doi.org/10.3171/jns.1999.91.5.0750

4.Annergers J. The risks of epilepsy after traumatic brain injury. Seizure 2000;9:453-7.

http://dx.doi.org/10.1053/seiz.2000.0458

5.Benardo LS. Prevention of epilepsy after head trauma: Do we need new drugs or a new approach. Epilepsia 2003;44(suppl. 10):27-33.

http://dx.doi.org/10.1046/j.1528-1157.44.s10.2.x

6.Kraus JF, McArthur DL. Epidemiologic Aspects of Brain Injury. Neurol clin 1996;14:435-50.

http://dx.doi.org/10.1016/S0733-8619(05)70266-8

7.Shandro JR, Rivara FP, Wang J, Jurkovich GJ, Nathens AB, MacKenzie E. Alcohol and Risk of Mortality in patients With Traumatic Brain injury. J Trauma 2009;66:1584-90.

http://dx.doi.org/10.1097/TA.0b013e318182af96

8.Bolçone OJ, Leme EMMT. Conjuntura Econômica São José do Rio Preto 2008.23rd Edition. São José do Rio Preto, SP: Secretaria Municipal de Planejamento e Gestáo Estratégica, 2008, 90p.

9.Sorani M, Lee MBA, Kim H, Meeker MRN, Manley G. Racel Ethnicity and Outcome After Traumatic Brain Injury at a Single, Diverse Center. J Trauma 2009;67:75-80.

http://dx.doi.org/10.1097/TA.0b013e31818234e8

10.Claassen J, Mayer SA, Hirsch LJ. Continuous EEG monitoring in patients with subarachnoid hemorrhage. Journal of clinical neurophysiology 2005;22:92-8.

http://dx.doi.org/10.1097/01.WNP.0000145006.02048.3A

11.Perel P, Edwards P, Wentz R, Roberts I. Systematic review of prognostic models in traumatic brain injury. BMC Med Inform Decis Mak 2006;6:38-48. http://dx.doi.org/10.1186/1472-6947-6-38

12.Fleminger $\mathrm{S}$, Ponsford J. Long term outcome after traumatic brain injury. BMJ 2005;331:1419-20.

http://dx.doi.org/10.1136/bmj.331.7530.1419

13.Perel P, Edwards P, Wentz R, Roberts I. Systematic review of prognostic models in traumatic brain injury. BMC Med Inform Decis Mak 2006;6:38-48. http://dx.doi.org/10.1186/1472-6947-6-38

14.Koizumi MS, Lebrão ML, Mello-Jorge MHP, Primerano V. Morbimortalidade por traumatismo crânio-encefálico no município de São Paulo 1997. Arq Neuropsiquiatr 2000;58:81-9.

http://dx.doi.org/10.1590/S0004-282X2000000100013

15.Queiroz, MS, Oliveira PCP. Acidentes de trânsito: Uma análise a partir da perspectiva das vítimas em Campinas. Psicologia e Sociedade 2003;15:1-15.

16.Durkin MS, Olsen SMA, Barlow B, Virella A, Connolly ES. The Epidemiology of Urban Pediatric Neurological Trauma: Evaluation of, and Implications for, Injury Prevention Programs. Neurosurgery 1998;42:300-10.

http://dx.doi.org/10.1097/00006123-199802000-00052 